RESEARCH PAPER

\title{
"Asian yuppies... are always looking for something new and different": creating a tobacco culture among young Asians
}

\author{
J Knight, S Chapman
}

Tobacco Control 2004;13(Suppl II):ii22-ii29. doi: 10.1136/tc.2004.008847

See end of article for authors' affiliations

Correspondence to: Dr Jennifer Knight, School of Public Health, Room 129A, Edward Ford Building (A27), University of Sydney, NSW 2006, Australia; knightj@health. usyd.edu.au
S moking in Asia has traditionally been a male activity; cigarettes were of low quality and made by inefficient state owned monopolies which bothered little about advertising and marketing strategies. Over the past 20-30 years enormous changes have occurred, altering substantially this traditional profile.

The threat of section 301 sanctions from the US Government $^{1}$ in Japan (1986), Taiwan (1986), South Korea (1988), and Thailand (1990), the rapid growth in the free markets of Hong Kong, Singapore, and Malaysia, and the easing of trade restrictions in countries such as China, Vietnam, and Myanmar (formally Burma) saw the widespread introduction of American cigarettes throughout Asia. Along with the cigarettes came sophisticated advertising, large scale marketing campaigns, and milder cigarettes. Smoking rates among young men and women have risen despite traditionally low rates and (particularly for women) strong cultural taboos (based on established customs and socio-religious constraints which prevented many women from smoking).

In Taiwan, for example, the rate of female teenage smokers rose from $5 \%$ in 1984 to $13 \%$ in $1987,{ }^{2}$ smoking among young adult Japanese women increased by 27\% from 1986 to 1991, and in South Korea rates among teenage males rose from $18 \%$ to $30 \%$ and among teenage females from $2 \%$ to $9 \%$ from 1988 to $1989 .{ }^{1}$

US based tobacco control advocate Dr Greg Connolly has noted that "when the multinational companies penetrate a new country, they not only sell US cigarettes but they transform the entire market. ...They transform how tobacco is presented, how it's advertised, how it's promoted. And the result is the creation of new demand, especially among women and young people". ${ }^{3}$ Similar claims were made by Ted Chen when appearing before the US Interagency Committee on Smoking and Health in 1988: "they [US cigarette companies] have tried to create an atmosphere of smoking for youth and women to associate smoking American cigarettes to American lifestyle or realizing American dreams". ${ }^{4}$

It is this process of creating an "atmosphere of smoking" and transforming "how smoking is presented" in Asia which is the focus of this paper. The paper looks at the process of creating a "new demand" among Asia's young men and women.

The concept of creating a tobacco culture is not new. The term has been used by, for example, Amos who writes of "creating a global tobacco culture among women". ${ }^{5}$ Philip Morris (PM) spoke of creating "a niche - a following - a cult - among Asian yuppies." ${ }^{7}$

The introduction of Virginia Slims (VS) into Asian markets provides a particularly transparent case study of the industry's attempt at constructing a female smoking culture where there was low demand for the product. When introduced into Hong Kong (HK) for example, only $1 \%$ of women smoked. ${ }^{8}$ Yet, despite a global industry policy of claiming that advertising only targeted brand switching among current smokers, PM's local distributor anticipated the product would "create [a] market demand" to meet "the future growth of female smokers segment instead of suiting the market needs in (sic) present".'

While others have documented examples of this process in an anecdotal fashion, ${ }^{10-16}$ this paper differs in that its primary source is the internal tobacco industry documents. The documents show that industry used a number of vehicles

Abbreviations: ASEAN, Association of South-East Asian Nations; BAT, British American Tobacco; BTL, below the line; FCTC, Framework Convention on Tobacco Control; HK, Hong Kong; ITPMS, International Tobacco Products Marketing Standards; JTI, Japan Tobacco International; PM, Philip Morris; Horeca, hotel, restaurant and café; SEA, South-East Asian; TGMP, target group meeting point; TLSS, Team Lucky Strike Suzuki; VS, Virginia Slims 
in constructing its culture of tobacco. These included music, entertainment, adventure, sport, glamour, and independence.

\section{METHODS}

The source material for this paper came from primary and secondary online tobacco document collections. In addition to the manufacturers' websites ${ }^{17} 18$ material came from Tobacco Documents Online (particularly the Guildford Miscellaneous collections). A total of 115 documents were retrieved. Further details of search procedures used and the limitations inherent in the use documents of this nature are to be found in http://tobacco.health.usyd.edu.au/site/ gateway/docs/pdf/Regional.pdf.

\section{RESULTS}

In constructing its culture of tobacco among young Asians the industry trialled pack design changes (HK's Viceroy pack was changed to "appeal to younger smokers"19) and line extensions (British American Tobacco (BAT) planned to "utilise line extensions ...to maximise growth among the young adult segment" ${ }^{\prime 20}$ ). Its main efforts were however expended in promotions involving a range of youth culture vehicles. *

\section{Music}

The companies placed high value on music throughout Asia. PM International noted that:"[T]oday's young adults react more to music and images than print. Music is their language and source of ideas and trends. It gets their attention and has universal appeal which transcends cultural boundaries". ${ }^{23}$ BAT's various advertising agencies also placed considerable importance on music as a medium to appeal to the target group. Grey Pacific, for example, stated that music "reflects the culture, aspirations and lifestyle that is most popular at the time among mass public". ${ }^{24}$ The agency also spoke of music's "universal appeal and positive influence among target smokers". ${ }^{24}$ BAT's Myanmar agency saw music as providing a "unique ongoing platform to appeal to ASU30 [adult smokers under 30 years]". ${ }^{25}$ In a number of countries, the industry tapped into music's appeal through sponsoring radio programmes. ${ }^{723}$ These invariably included thematic commercials and often contests. In China Marlboro sponsored a bilingual programme, "Marlboro Music Hour", to "project a contemporary image". ${ }^{26}$ In HK, PM sponsored the "Top of the Charts" programme. ${ }^{7}$ PM saw this as a "bridging device" which was an "interesting way to cross the cultural barrier" and to associate Marlboro "with top US songs in an appealing format for local fans, thereby capturing a big audience and generating a positive image for the brand". ${ }^{7}$ The Indonesian programme "Marlboro Country No 1 Sounds", based on USA billboard country music charts, had an estimated eight million listeners. ${ }^{\text {? }}$

In China PM decided to establish brand imagery for its Parliament brand through jazz, despite jazz being "still limited to a minority". ${ }^{27}$ Pre-event publicity had to take an "educational approach" (that is, jazz workshops and the establishment of a jazz library ${ }^{27}$ ) to generate an interest in jazz among the general public. ${ }^{27}$

\section{Entertainment}

\section{Discos and nightclubs}

The involvement of the tobacco industry in North American ${ }^{28-30}$ and Australian ${ }^{31} 32$ bars and nightclubs has been documented. Activities undertaken by industry included venue sponsorship along with cigarette brand paraphernalia,

*See Assunta and Chapman ${ }^{21} 22$ for additional examples within the Malaysian context. advertisements, and entertainment events. The initiative was exported to Asian discos, karaokes, bars, and nightclubs. BAT, for example, utilised the nightclub scene in a number of Asian countries to promote its 555 brand. In 1994 BAT used the Nightman Disco in Beijing to provide "good media exposure ...for 555 brand". ${ }^{33}$ In the inimitable language used by marketers, the 555 Club in Taiwan was seen as "a meaningful way of adding value to the 555 brand imagery, contemporazing the brand, and building a valuable relationship with end-users". ${ }^{34}$ In Myanmar, in the late 1990s, BAT developed a "mutually beneficial partnership" with Club Pioneer, the capital's "premier night club". ${ }^{35}$ With BAT's help, Club Pioneer became "the hottest centre for trend setting upper-income young adults in Yangon." ${ }^{\prime 36}$ The aim of the partnership was to run events that were "superior to any similar events conducted by the competition" ${ }^{\prime 35}$ to make "both the Brand and Club Pioneer the "talk of the town".". ${ }^{35}$

As in Australia, nightclub promotions were used to target young women..$^{31}{ }^{32}$ In Taiwan PM conducted a series of fashion shows in discos. The objective was to "acquaint customers with the brand's image [and] ...to reach the target market, 18-35 year olds" 137 as well as "to convey the VSL [Virginia Slims Lights] fashion image to target consumers under a fashion show set up". ${ }^{38}$ The format was quite simple: at "the most crowded time of the night" modelled clothing on the disco floor. Brand visibility was enhanced with venue decorations and the use of the VSL jingle throughout. ${ }^{38}$

The ability of bar promotions to facilitate brand sampling and brand trial has been identified as being of key importance to the industry. ${ }^{30}$ PM Asia considered sampling an "important marketing device" as it got "the product into the consumers' hands". ${ }^{37}$ The company conducted sampling in a range of venues across a number of nations. Examples included the Taiwanese disco fashion shows where sampling teams mingled among the audience, ${ }^{37}$ in China where sampling was conducted year round at "class-A venues", ${ }^{26}$ and throughout HK's PMSL (Philip Morris Super Lights) campaign when sampling teams visited popular discos, karaokes, and bars. ${ }^{39}$ BAT utilised the idea in, for example, Myanmar where sampling was conducted weeks before special events at the Club Pioneer. Sampling was not haphazard-it concentrated "on youth high traffic Horeca [hotel, restaurant and cafe] outlets"..$^{40}$

Giving out branded promotional items and incentives in nightclubs has been used to increase brand visibility. ${ }^{30}$ BAT used the idea in Yangon by giving 555 branded CDs as a "prestige door-gift" to those attending its Universe Dance Action Party and at the Cosmos Night where the gift was considered "a prestigious memento ...expensive, prestigious and relevant for ASU-30". ${ }^{41}$

Nightclub promotions have been used by industry to generate names for their databases. ${ }^{30}$ In Taiwan a primary objective of the 555 Club was to develop a database "well in advance of the pending ban" (emphasis in original) $\overline{{ }^{34} \mathrm{In}}$ Singapore just months before the introduction of legislation banning such events, disco promotions were conducted not only "to maintain a presence in popular nightspots of young adults $^{\prime 37}$ but to generate names for the company's database which was used once legislation was introduced. ${ }^{37}$

Target group meeting point (TGMP) promotions were an "inexpensive way of collecting targeted smoker names for our database."7 TGMPs were "product, advertising or event related games conducted at night-life spots where the target group spends their leisure time" ${ }^{37}$ The activities were also used to "involve consumers in brand activities in an engaging and fun way". ${ }^{7}$ PM used the strategy in HK to increase pack recognition, reinforce advertising, test marketing concepts, ${ }^{37}$ and heighten awareness of sponsorships. ${ }^{7}$ 
The intense competition for young adult smokers has, according to Katz and Lavack, "forced" tobacco companies to introduce new and more exciting promotions. ${ }^{30}$ As a result of this trend, promotions have become "increasingly creative and diverse ${ }^{\prime \prime},{ }^{30}$ such as BAT's 555 promotions in Myanmar in the late 1990s. The 555 "staying cool when it's hot" theme involved disco DJs announcing a series of "555 breaks" throughout the evening. ${ }^{42}$ The music was lowered, and dark blue and yellow icy cold towels, along with free drinks (blue alcoholic drink or yellow coloured lemonade), were distributed. ${ }^{42}$ Innovative ideas employed on other evenings included the use of robots to escort dancers to the dance podiums ${ }^{40}$ and the distribution of "genuine Dr Spock glue-on ears" to ASU30 entrants $^{41}$ while waiters and promotion team members wore space helmets with blinking LED lights. ${ }^{41}$

Theme nights have also been used throughout Asia as another form of nightclub promotion. In Taiwan, PM held theme parties at Christmas time designed "to create a 'fun' atmosphere with strong visibility and to promote the brand image and awareness among VSL's target audience" ${ }^{\prime \prime}{ }^{37}$ The parties, held in popular discos, were extravagant events and included magicians dressed as Santa Claus performing magic and distributing gifts, Polaroid photos taken of guests with Santa, entry gift packs, and lucky draw prizes. ${ }^{37}$ PM exported the idea to HK where popular discos were decorated with bunting, Christmas trees, and other supporting material including sampling and TGMP games. ${ }^{43}$

\section{Movies}

PM Asia considered movie sponsorship to be "an effective way to reach more upscale Marlboro Lights smokers". ${ }^{7}$ Movie sponsorship was undertaken by PM in HK, China, ${ }^{7}$ and $\operatorname{Japan}^{37}$ and by BAT in, for example, Myanmar ${ }^{44}$ where its "American Original Movie Series" featured classics such as the Indiana Jones and Terminator series. ${ }^{44} 45$

\section{Adventure}

PM exported the Marlboro Adventure Team concept to Asia in the early 1990s. One of the concept's key objectives was "to boost volume and share among YAMS [young adult male smoker]." ${ }^{46}$ The programme enabled contest winners from HK, Taiwan, and Malaysia to spend nine "action-filled days" in the American West. Scheduled activities included motor cross dirt biking, guided horseback riding, a scenic flight over the Grand Canyon, a night in Las Vegas, white water rafting, a two night cattle drive, and other "authentic Western activities $^{\prime \prime 4}$. The overall cost of the project was in excess of US\$500 000 which equated to US\$170 300 per participating country or $\$ 10200$ per participant. ${ }^{46}$

\section{Sport}

The industry had a deep appreciation of the role sport played in the lives of young Asian males. According to PM Asia "[S]port is by far the best avenue to attract, sample and influence our core target". ${ }^{7}$ PM considered sport to be "THE socially acceptable head to head combat machine that makes 'challenge' the war cry. Sport will be the catalyst that will allow TMD [trademark diversification] to become acceptable ${ }^{\prime \prime} .{ }^{47}$ The appeal was not limited to young men. Mackay and Amos note that, although it is mainly men's sports that are sponsored in developing countries, these are also watched by millions of women. ${ }^{10}$ In 1993, for example, $46 \%$ of spectators at the HK Salem Tennis event were women. ${ }^{10}$

The industry employed the full gamut of sports to promote its products: motorsport (formula one (F-1) racing, rally, ${ }^{48} 49$ motorcycles), water sport (beach volley ball, ${ }^{50}$ windsurfing, ${ }^{51}$ sailing, ${ }^{51}$ powerboat races, ${ }^{51}$ and waterskiing contests ${ }^{51}$ ), badminton, ${ }^{52}$ football/soccer, and tennis.

\section{Motorsport}

BAT realised that "the motorcycle racing audience is consistent with our target audience" ${ }^{\prime \prime 53}$ and, accordingly established a longstanding and international sponsorship arrangement with the motorcycle company Suzuki: the Team Lucky Strike Suzuki (TLSS). TLSS's objective was to "build and enhance brand image among target consumers" ${ }^{54}$ According to BAT "Lucky Strike is the maverick spirit of Grand Prix motorcycle racing...the emotional characteristics of Grand Prix racing complement the brand's characteristics...masculine, adventurous and challenging. ${ }^{55}$ These characteristics flowed through to the TLSS slogans: "Some men have winner written all over them", "The mark of a winner", and "Who dares wins". ${ }^{56}$

Motorcycle racing was extremely popular throughout Asia where, in 1994, it was watched by a cumulative 209 million viewers. ${ }^{54}$ TLSS' popularity is reflected in the sale of over 6000 replica bikes in Japan alone. ${ }^{57}$ Research showed TLSS to be "relevant and high profile among brand's core target audience and consistent with and enhancing to the brand's image". ${ }^{57}$ BAT was ecstatic. It saw Lucky Strike as a "top priority brand" which could "help cure BATCo's weakness amongst the YAUS [young adult urban smoker]". ${ }^{58}$

PM's involvement with motorcycles featured large exhibitions such as the "Marlboro Superbike Show" held in Taiwan. ${ }^{59}$ The show included exhibits of Marlboro grand prix racing bikes, US classic bikes, and other high powered motorcycles and was, according to PM, "a big success, drawing large attendance and extensive publicity". ${ }^{59}$ The show's objective was "to strengthen Marlboro's brand image...with excitement, vitality and masculinity, especially among young adult consumers".59 In a country with approximately one motorcycle for every three people, motorcycles are extremely popular yet government regulations limited the power of those bikes to 125 cc or less. As a result, there was a "strong aspiration toward high-powered motorcycles" into which PM tapped..$^{59}$ Not surprisingly, PM concluded that "motorcycle lovers demographics match those of Marlboro target market". ${ }^{59}$

Industry's involvement in motorsports was not limited to motorcycles. It also had a long association with F-1 racing. Its objectives for entering F-1 sponsorship were spelt out clearly by BAT: "add excitement and dynamism to the brand position" and "enrich the brand's sophisticated, quality, upscale image". ${ }^{60}$

PM had a long term association with F-1 racing through its association with the McLaren racing team. The company saw F-1 as "highly targeted, heroic and international"7 and, in its own words, "capitalized on Marlboro MacLaren's unprecedented performance in F-1...as a way to reinforce Marlboro's leadership image and to secure a strong young adult male association with a dynamic and exciting sport". ${ }^{7}$

BAT noted the success of this PM strategy: "the glamorous upmarket image [of F-1] compliments Marlboro's premium product positioning, while at the same time reaching a wide audience around the world". ${ }^{61}$ BAT astutely observed the link between F-1 and Marlboro's traditional image:

\section{"it [F-1] is synergistic with the cowboy; having the same themes of power, independence and freedom, but with the added benefit of having more contemporary relevance to the real world. The success of the McLaren motor racing team (the cowboy is the hero, Prost is the hero) has strengthened Marlboro's world beating image...". ${ }^{61}$}

Not to be outdone, BAT launched its own F-l racing team: British American Racing (BAR) in $1999 .{ }^{62}$ The decision has resulted in "internationalizing" ${ }^{62}$ BAT brands by providing 
extended television exposure, creating merchandising opportunities targeting young adults, and reaching key Asian markets through planned race sponsorship. ${ }^{62}$

Neither PM nor BAT limited their involvement in F-l to those countries hosting races. In China, for example, where the "key target group" had, up until that point, "absolutely no exposure to F-1 racing", ${ }^{7}$ PM introduced F-1 to "enhance our heroic and import image and to begin building interest". ${ }^{7}$ (China's first F-1 race was held in Shanghai on 26 September $2004^{63}$ ). In other countries such as Indonesia and HK PM sought to "enhance young adult consumer involvement in the absence of a physical F-1 event" ${ }^{\prime 7}$ and "enable our young adult consumers to get hands on involvement with F-1" ${ }^{\prime \prime 7}$ by staging exhibitions featuring the McLaren F-l car, along with an assortment of rally cars, motorcycles, and biplanes, and dramatic video, simulator, and audiovisual presentations. ${ }^{7}$

Similarly, BAT promoted its F-l involvement in countries that did not host F-1 races. In Indonesia, for example, BAT's 1999 "Racing Exploitation" plan sought to "increase brand awareness" through an extensive PR and media campaign that included TV, print, and radio advertisements as well as Horeca promotions, racing parties, and direct marketing. ${ }^{64}$

The industry has a longstanding and dominant presence in motorsport ${ }^{65}$ with sponsorship of motor racing "one of the major promotional activities" ${ }^{\prime \prime 6}$ used by the industry. Industry was very clear on its motive behind this strong support. In reference to BAT's sponsorship of the Macau Grand Prix, Gordon Watson, general manager in HK, for example, stated:

"We're not handing out money for nothing. We have gone into this very thoroughly and the entire JPS publicity is built around motor racing, seen as a fast, exciting, trendy sport for the young... That's who we are aiming at in the local market..."67

Similar comments were made by BAT with reference to its sponsorship of the HK-Beijing rally: "the rally series provides the opportunity to generate increased 'big' brand awareness via TV coverage, building on the core values of internationalism, contemporanity and popularity." ${ }^{\prime \prime 8}$

\section{Soccer/football}

Soccer is an extremely popular sport throughout Asia. In China it was considered "the most popular sport". ${ }^{26} \mathrm{PM}$ ensured that the sport became "Marlboro property" ${ }^{26}$ through sponsorship of two major events- the annual Marlboro Cup Tournament in Shanghai and the bi-ennial Marlboro Dynasty Cup. ${ }^{26}$ The Dynasty Cup was an eight year agreement with the Asian Football Confederation drawing teams from China, Japan, North and South Korea. The Cup's draw card was the possibility of watching teams from both North and South Korea play-an opportunity potentially seen only at Olympic or World Cup competitions. ${ }^{7}$

PM also sought to link itself with World Cup football wherever possible. In the lead up to the 1990 World Cup, for example, PM secured the rights to produce a comprehensive "World Cup Guide Book" which it distributed to young adult leagues in South Korea and China. ${ }^{7}$ In the lead up to the 1994 World Cup PM sponsored a "Road-to-USA" TV series in China. ${ }^{26}$

BAT was not to be outdone. In Myanmar it sponsored telecasts of English Premier League games and linked its promotion of 555 with its Score-a-winner promotion. ${ }^{36}$ And as will be discussed, BAT also sponsored the 2002 World Cup in Malaysia. ${ }^{69}$

\section{Tennis}

Both PM and RJ Reynolds (RJR) ${ }^{70}$ had a strong association with tennis in Asia. In 1987 PM began sponsoring the HK
Marlboro Tennis Championship. The event involved the world's top 16 male tennis players competing for Asia's largest prize money. The event became the "region's most significant men's tennis event". ${ }^{7}$ Early rounds were played in Seoul, Manila, and Beijing as well as HK to maximise exposure; sampling and sales of branded merchandise were used to "complement" the game; and multiple year contracts were signed with top ranking players.

Chinese American player Michael Chang "enjoyed idol status" with many Asian teenage girls ${ }^{10}$ and PM considered his involvement to be a "coup"7: "we have been successful in drawing an unusually targeted audience...in great part due to Michael Chang's enormous popularity". ${ }^{7}$ In a ploy reminiscent of the US\$60 000 a year deal struck between tennis great Billie Jean King and PM USA, ${ }^{71}$ PM Asia paid Chang US\$80 000 (tax free) in 1992 over and above his tournament appearance and any winnings. ${ }^{72}$

Whatever its form, industry was committed to using sport:

"For the future we will continue to promote sports events which make good business sense. They are important to our continued growth and prosperity and to the continued development of the communities in which we have business interests. ${ }^{\prime \prime 2}$

\section{Glamour}

The industry's appeal to young women with themes highlighting sophistication and glamour are well documented. ${ }^{5}{ }^{11} 73$ With particular reference to Asia, Ernster et al have noted that:

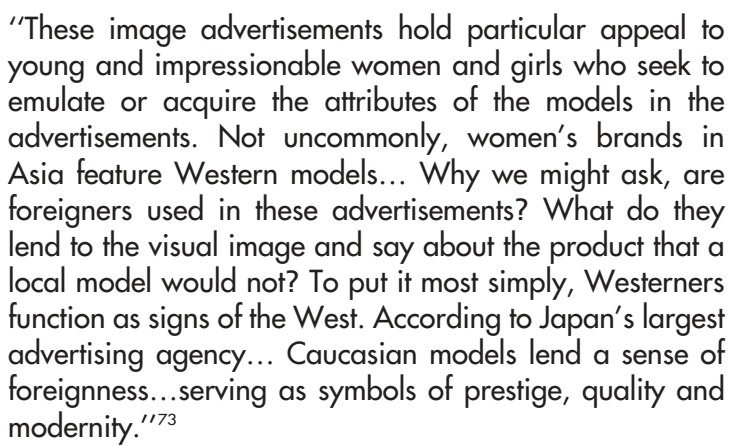

A BAT document entitled "Guidelines for photography" backs this assessment, instructing that "talent must not be Asian"74 and the majority of models "should look western". ${ }^{74}$

In creating this tobacco culture among the young women of Asia industry was quite specific in its demographics, with one internal document referring to plans "to target the emerging young adult female smokers rather than the older female smokers". ${ }^{75}$

During the early 1990s PM had active below the line (BTL) programmes in HK, Japan, South Korea, Guam, Singapore, and Taiwan. BTL programmes utilise non-traditional mediums to advertise and promote and include a range of promotional strategies excluding television, print, and poster advertising (see Carter $^{76}$ for further discussion). The programmes sought to construct a sense of glamour through the promotion of beauty and fashion. Three industry documents $^{37} 3877$ reveal a host of activities associated with these programs. The documents are particularly insightful as they include photographs taken at various activities.

\section{Beauty}

PM introduced a beauty salon programme into Taiwan and Japan which provided an opportunity for "on target brand exposure to build up the VS image" ${ }^{37}$ The programme was 
developed "to strengthen the brand's fashion image". ${ }^{38}$ In many respects the beauty salon programme resembled the disco promotions discussed above. Many of the same brand stretching strategies were used: sampling; the generation of names for industry databases; distribution of branded promotion items (Polaroid photos were taken of "after" hairstyles and framed in branded holders ${ }^{38}$ ) and brand visibility (VS logos on salon mirrors and ashtrays ${ }^{77}$ ).

\section{Fashion}

A diverse range of VS promotions centred around fashion. In September 1989, for example, VS sponsored the Hong Kong Fashion Designers' Association Show honouring the year's top designers. In the opinion of PM the event "provided an opportunity to sponsor an important local event in the fashion field". ${ }^{37}$

In the months following the show VS ran a series of "advertorials" in the country's two popular fashion magazines. ${ }^{37}$ The objective of the initiative was to "strengthen VS' association with fashion"-an achievable goal given that women's magazines are one of the most popular media for targeting women. ${ }^{5}$ VS followed this by focusing on "the fashionable, international image" of the brand ${ }^{38} 77$ and provided participants with opportunities to win prizes. ${ }^{38}$

Subsequent advertising bans in HK did not deter the industry. In an attempt to circumvent legislation PM ran a fashion competition in 1997 entitled "My Journey" with prizes including shopping sprees in Milan and New York. ${ }^{78}$

Taiwan also promoted the fashion theme. Its fashion nights were designed to "reinforce the fashionable, trendy and fun image of VSL and also to create more innovative sampling opportunities". ${ }^{77}$ The evening included themed decorations, sampling (dispensers on every table and distribution at the entrance by sampling teams even though, under Taiwanese legislation, sampling was restricted to one stick $\left.^{79}\right)$, and lucky draws. ${ }^{77}$

PM also organised a "VS fashion shoot program" in Taiwan to "strengthen brand's fashionable image and maximise media exposure under cigarette advertising restrictions". ${ }^{38}$ Using high traffic locations the format simulated real fashion photo sessions. Brand exposure was achieved by on-the-spot visibility from ID on crew's uniforms, vehicles, and props as well as editorial coverage in fashion magazines. ${ }^{38}$

\section{Independence}

PM's marketing ploy of aligning VS with the changing roles of women is well documented. ${ }^{5}{ }^{730-83}$ For many women in the developed world the catchy "you've come a long way baby" epitomised the social and occupational progress they were making during the 1970s and 1980s. Importing the brand into Asia called for some modifications, however. PM Asia strove to "maintain the essence of what made it work in the US but provide for cultural or market environment differences". ${ }^{84}$ Accordingly, Japanese advertisements were, for example, modified to take into account the "less-liberated state of Japanese women" ${ }^{84}$

PM employed a number of strategies around the independence theme. In HK, for example, a TGMP entitled "Are you an independent woman?" was devised. Based on a series of questions and scenarios participants compared their answers with supposed research findings on "independent" women. ${ }^{38}$ While the game may have engendered a sense of independence among participants it was nothing less than a chance to generate names for the company's database. ${ }^{38}$

\section{DISCUSSION}

The tobacco industry believed it needed to construct a culture in which, despite tradition and social history, smoking would become desirable or even normalised for young men and women. As it has always done, it set about creating this atmosphere by appropriating vehicles that included music, entertainment, sport, adventure, fashion, and the emancipation of women and proposing that smoking was an apposite and integral part of these milieu.

These six vehicles were not chosen randomly, but following intensive research at both the national and regional levels. In depth studies were conducted in $\mathrm{HK}^{85-87}$ Taiwan, $^{88}$ Malaysia, ${ }^{89} 90$ Singapore, ${ }^{89}$ and Thailand.$^{89}$

Intrinsic to all six vehicles utilised by the industry was the promotion of the Western ideal of what is beautiful, fashionable, and "cool". In his submission to the Interagency Committee on Smoking and Health, Office of the US Trade Representative, Chen identified one the industry's marketing strategy that sought "to create an atmosphere for teenagers to associate smoking American cigarettes with an American lifestyle, or realizing the American dream". ${ }^{2}$ In linking American cigarettes with the American dream, the industry ipso facto devalues the indigenous Asian cultural identity and norms. This insidious form of social and cultural imperialism sees many young Asian men and women strive to adopt "the American dream" readily-seemingly unquestioningly. Whether they know it or not they do so at the risk of disregarding, even discarding, their own culture and heritage. Strengthening cultural identity is the first step to countering the use of Western images and models as enticements to tobacco use.

Gaining an understanding of the way the industry constructed a culture receptive to smoking provides insights into ways that same culture might be dismantled by tobacco control groups. In response to the success of the tobacco industry in creating an environment in which smoking is increasingly acceptable, tobacco control advocates, public health authorities, and politicians must strive to construct a social, economic, and political climate which actively discourages smoking and promotes non-smoking as the norm. ${ }^{6}$ This will require coordinated action at the international, regional, national, and community level.

Many of the activities identified now no longer occur as blatantly as a result of legislation introduced in nations such as Singapore, Thailand, Vietnam, HK, and South Korea. However, the transnational nature of several of the strategies discussed requires a much broader approach be taken. As the industry's global strategies such as product placement in entertainment and fashion and internet advertising transcend national boundaries, so tobacco control measures must increasingly depend upon global agreement and action, as well as strengthening national policies.

Worldwide cooperation in tobacco control is currently being fomented through the World Health Organization's Framework Convention on Tobacco Control (FCTC). This international legal instrument is designed to curb the global spread of tobacco use through specific protocols covering, among other things, advertising and sponsorship. The potential of the FCTC to advance multilateral cooperation and effective action for tobacco control worldwide is enormous and there is widespread optimism surrounding its possibilities.

At the regional level, support for the FCTC has come from the Association of South-East Asian Nations (ASEAN), the region's foremost economic group. In September 2002, the 2nd ASEAN inter-sessional meeting on the FCTC resolving that "the governments of ASEAN countries shall work collectively at the regional level as well as under the FCTC process to advance the objectives of tobacco control". ${ }^{91}$

Several major regional and international sporting bodies have acted in advance of the FCTC implementing agreements to curb tobacco advertising and sponsorship. The Olympic 
Games, for example, went tobacco-free in $1988^{92}$ and the Federation Internationale de Football Association (FIFA) declared World Cup events to be tobacco-free following the 1986 World Cup in Mexico. ${ }^{93}$ The 2003 South East Asian (SEA) Games and the ASEAN Para Games held in Vietnam were tobacco-free and smoke-free and, on World No Tobacco Day earlier this year, host nation, the Philippines, announced the 2005 SEA Games would also be smoke-free. ${ }^{94}$

These initiatives do not, unfortunately stretch to the very influential sport of motor racing where the Federation Internationale de l'Automobile's (FIA) World Motor Sports Council has a mixed track record. In 2000 the Federation resolved to ban tobacco advertising and sponsorship at the end of its 2006 season (conditional upon "entry into force" of the FCTC ${ }^{95}$ ). Despite the FIA's claim that the proposed ban demonstrated their commitment "to working constructively with public authorities on the issue of tobacco sponsorship", ${ }^{95}$ the undertaking was short lived. In December 2002 the FIA threatened to take the sport out of an increasingly regulated Europe. ${ }^{96}$ In June the following year it went one step further and announced the intended ban would be replaced with a recommendation that tobacco sponsorship should cease. ${ }^{97}$ In announcing the FIA decision the BBC pointed out that three of F-1's top four teams-Ferrari, McLaren, and Renault-have tobacco sponsors that "pay a large chunk of their budgets". ${ }^{97}$

In response, the tobacco industry announced an International Tobacco Products Marketing Standards (ITPMS) in September 2001. ${ }^{98}$ Supported by BAT, PM and Japan Tobacco International (JTI), the code, which came into effect at the end of 2002, is supposed to prevent sales activities specifically tailored to appeal to young people. ${ }^{98}$ Given industry's track record of using self regulation as a means of circumventing legislation, industry's move has been met with total cynicism by the tobacco control community. A WHO spokesman, for example, viewed the standards as "just another attempt by the industry to persuade governments that there's no need for a strong framework convention". ${ }^{99}$

Incidents such as occurred in Malaysia during the 2002 World Cup justify this cynicism. At that time BAT (a signatory of the ITPMS) flagrantly flouted FIFA's tobacco-free policy and sponsored the Cup's telecast in Malaysia (with cross border "intrusion" into parts of southern Thailand where tobacco advertising and sponsorship are illegal $^{100}$ ). A US\$5million advertising campaign backed the telecast. ${ }^{69}$ FIFA was accused of turning a "blind eye"101 to the deal which enabled it to ban tobacco related advertising and the sale of tobacco products in Cup stadiums but seemingly unable to control soccer related ads that were not directly linked to either FIFA or the World Cup. ${ }^{102}$ National governments, tobacco manufacturers, and local broadcasters are currently able to override the stated goals of FIFA. ${ }^{102}$ Introduction of the FCTC will ensure such incidents are not repeated in future World Cup events.

This paper has identified two key female aspirations exploited by the industry in promoting the construction of a tobacco culture among young women. Industry's attempts to link smoking with images such as glamour, fashion and independence as well as affluence, sophistication, modernity, and success are well documented, ${ }^{511} 7380-82103$ as is the much broader issue of women and smoking. Women and smoking has been the topic of international conferences (for example, the 1999 WHO International Conference on Tobacco and Health $^{104}$ ), two US Surgeon General's reports, ${ }^{105}{ }^{106}$ and the impetus for the formation of international (International Network of Women Against Tobacco) and Asian based women's anti-tobacco organisations (see Ernster et $a l^{73}$ and Bianco $^{107}$ for examples).

\section{What this paper adds}

Industry's attempts to make smoking desirable, even normalised, to Asia's young men and women is well documented. This paper differs in that it draws upon the industry's internal documents rather than anecdotal material. The documents show that industry used six vehicles to construct a culture of tobacco: music, entertainment, sport, adventure, glamour, and independence. Understanding the way industry constructed this culture provide insights into the ways it might now be overturned. Tobacco control advocates, public health authorities, and legislators must strive to construct a social, economic, and political climate which actively discourages smoking and promotes non-smoking as the norm.

Given that selling tobacco products to women currently represents the "single largest product marketing opportunity in the world"11 for the industry, those seeking to erode the tobacco culture industry has specifically promoted among women will need all the assistance they can muster. The Asian based anti-tobacco organisations must be mobilised as strong advocates to prevent further increases in smoking among women and girls in their region and ensure the actions of the transnational tobacco companies are in keeping with their own standards as set out in the ITPMS. Regional and international mechanisms (such as the Kobe Declaration on Women and Tobacco and the Beijing Platform for Action) must be employed in strengthening national tobacco policies. The large body of research, particularly that pertaining to Asia, must be used to influence policymakers and legislators to introduce strong tobacco control measures and ratify the FCTC.

All national governments throughout Asia must support the FCTC. With particular reference to young women in countries undergoing fast urbanisation or industrialisation, measures must be taken to disassociate smoking from progress in achieving sex equity. While smoking rates have risen within this cohort, smoking prevalence is still relatively low-it must stay that way, and where increases have occurred any worrisome signs of increase in smoking among the group curtailed.

\section{ACKNOWLEDGEMENTS}

Thanks to Ms Fiona Byrne, Information Manager for the Australian and Asian tobacco documents project, for outstanding assistance in document location retrieval, and the reviewers for their insightful comments and feedback.

\section{Authors' affiliations}

J Knight, S Chapman, School of Public Health, University of Sydney, Sydney, NSW, Australia

Funding source: National Health \& Medical Research Council (Australia) \#153857 National Institutes of Health (USA) \#1 R01 CA871 10-01A1

\section{REFERENCES}

1 Chaloupka FJ, Laizuthai A. U.S. trade policy and cigarette smoking in Asia. Cambridge, Massachusetts: National Bureau of Economic Research, 1996 (NBER working paper; 5543).

2 Chen T. Supplementary information submitted for record: accompanying testimony of Ted TL Chen, Professor, School of Public Health, University of Massachusettes on behalf of the American Public Health Association on September 13, 1989 for export of American cigarettes. 13 Sep 1989. Tobacco Institute. Bates No. TIMN0304677/4692. http:// legacy.library.ucsf.edu/tid/kuk62f00.

3 Frankel G. US aided cigarette firms in conquests across Asia. Washington Post (Washington DC) 17 Nov 1996:A01-11.

4 Chen T. Comments by Ted TL Chen, consultant, Taiwan Health Department, Member, Executive board, APHA, Professor of Public Health, University of 
Massachusetts, Amherst, Massachusetts. Feb 1988. Philip Morris. Bates No. 2504047931/7938. http://legacy.library.ucsf.edu/tid/msx32e00.

5 Amos A. Creating a global tobacco culture among women, 1997. (Smoke free Europe - a forum for networks).http://www.health.fi/smoke2html/ Pages/Smoke2-23.html [Accessed 17 May 2004].

6 Amos A. Women and smoking. Br Med Bull 1996;52:74-89.

7 Philip Morris Asia. Marlboro. 1990. Philip Morris. Bates No. 2504034844/ 4875. http://legacy.library.ucsf.edu/tid/wfr19e00.

8 Mackay J. Women and tobacco: international issues. J Am Med Womens Assoc 1996;51:48-51.

9 Ho K. [Letter to Geoffrey Bible re: Virginia Slims]. 24 Oct 1989. Philip Morris. Bates No. 2023270424/0425. http://legacy.library.ucsf.edu/tid/ lcv36e00.

10 MacKay J, Amos A. Women and Tobacco. Respirology 2003;8:123-30.

11 Kaufman N, Nichter M. The marketing of tobacco to women: global perspectives. In: Samet J, Yoon S-Y, eds. Women and the tobacco epidemic: challenges for the 21 st century. Geneva: World Health Organization in collaboration with the Institute for Global Tobacco Control, Johns Hopkins School of Public Health, 2001:69-98.

12 INFACT. Update: Infact takes on the tobacco industry. Summer 1993. British American Tobacco. Bates No. 5026401 16/0124. http:// tobaccodocuments.org/mayo_clinic/29302477.html [Accessed 17 May 2004].

13 INFACT. Global aggression: the case for world standards and bold US action challenging Philip Morris and RJR Nabisco. New York: INFACT, 1998.

14 International Policy Conference on Children and Tobacco. Children and tobacco: a global crisis. 17 Mar 1999. Philip Morris. Bates No. 2069531569/1574. http://legacy.library.ucsf.edu/tid/gay32d00.

15 INFACT. Tobacco marketing to young people. Mar 1994. Philip Morris. Bates No. 2073953663/3664. http://legacy.library.ucsf.edu/tid/ vrs45c00.

16 Sesser S. New Yorker magazine. Opium war redux. 13 Sep 1993. Lorillard. Bates No. 83175416/5427. http://legacy.library.ucsf.edu/tid/boo43c00.

17 Philip Morris. http://www.pmdocs.com.

18 R.J. Reynolds. http://rirtdocs.com/rirtdocs/index.wmt?tab=home.

19 British American Tobacco. Management board meeting. $18 \mathrm{Dec} 1980$. British American Tobacco. Bates No. 300053346/3351. http:// tobacco.health.usyd.edu.au/tds/BAT300053346_3351 [Accessed 17 May 2004].

20 British American Tobacco Company Limited. Marketing strategy. 1992 British American Tobacco. Bates No. 301569014/9024. http:// tobaccodocuments.org/guildford misc/301569014-9024. html.

21 Assunta M, Chapman S. The tobacco industry's accounts of refining indirect tobacco advertising in Malaysia. Tobacco Control 2004;13(suppl II): ii63-70.

22 Assunta M, Chapman S. Industry sponsored youth smoking prevention programme in Malaysia: a case study in duplicity. Tobacco Control 2004; 13(suppl II):ii37-42.

23 Butson E. Marlboro country radio. 14 Jul 1988. Philip Morris. Bates No. 2504053690/3693. http://legacy.library.ucsf.edu/tid/mfx32e00.

24 Cheung C. Grey Pacific. Kent regional BTL concept: [fax to J, Cook, BATCo Staines]. 10 May 1993. British American Tobacco. Bates No. 500010132/ 0136. http://tobaccodocuments.org/guildford_misc/5000101320136. html [Accessed 17 May 2004]

25 Bates Advertising (Myanmar). Draft proposal for Benson \& Hedges sponsorship of the Myanmar Top 20. 7 Aug 1997. British American Tobacco (Non MSA). http://tobacco.health.usyd.edu.au/tds/BAT_MIS_00007 [Accessed 17 May 2004].

26 Philip Morris Asia. China OB 1994. 1994. Philip Morris. Bates No. 2504032809/2860. http://legacy.library.ucsf.edu/tid/wba42e00.

27 Philip Morris Asia. Parliament in the People's Republic of China. 25 Mar 1991. Philip Morris. Bates No. 2504053797/3816. http:// legacy.library.ucsf.edu/tid/ruv19e00.

28 Sepe E, Ling M, Glantz S. Smooth moves: bar and nightclub tobacco promotions that target young adults. Am J Public Health 2002;92:414-19.

29 Sepe E, Glantz S. Tobacco promotions in the alternative press: targeting young adults. Am J Public Health 2002;92:75-78.

30 Katz S, Lavack A. Tobacco related bar promotions: insights from tobacco industry documents. Tobacco Control 2002;11(suppl I):i92-i101.

31 Carter S. Worshipping at the Alpine altar: promoting tobacco in a world without advertising. Tobacco Control 2001;10:391-93.

32 Lawson V. Glamour puff. Tobacco Control 2003;12:3-5

33 Osborne S. General Manager's review: BAT China, December 1994. 13 Jan 1995. British American Tobacco. Bates No. 500101123/1134. http:// tobacco.health.usyd.edu.au/tds/BAT500101123_1134 [Accessed 27 Nov 2003].

34 K\&D Asia. Direct marketing for 555 brand in Taiwan: summary recommendation. 6 Aug 1992. British American Tobacco. Bates No. 500128957/8960. http://tobaccodocuments.org/guildford_misc/ 500128957-8960.html [Accessed 2 Jan 2004].

35 Bates Advertising (Myanmar). 555 State Express Club Pioneer proposal 11 Mar 1998. British American Tobacco (Non MSA). http:// tobacco.health.usyd.edu.au/tds/BAT_MIS_00004 [Accessed 17 May 2004].

36 Bates Advertising (Myanmar). 555 score-a-winner promotion. 4 Sep 1998 British American Tobacco (Non MSA). http://tobacco.health.usyd.edu.au/ tds/BAT_MIS_00010 [Accessed 17 May 2004]

37 Philip Morris Asia. Virginia Slims below-the-line programs: Hong Kong, Taiwan, Japan, Singapore. Apr 1990. Philip Morris. Bates No. 2504015964/6047. http://legacy.library.ucsf.edu/tid/miq19e00.
38 Philip Morris Asia. Virginia Slims below-the-line programs update: Hong Kong, Taiwan, Japan, Korea. Aug 1990. Philip Morris. Bates No. 2500152276/2329. http://legacy.library.ucsf.edu/tid/sfn 19e00.

39 Philip Morris Asia. Philip Morris Super Lights - looking ahead. 1991. Philip Morris. Bates No. 2504018360/8366. http://legacy.library.ucsf.edu/tid/ kau 19 e00.

40 Bates Advertising (Myanmar). 555 Cosmos night III: 28th August 1998 Club Pioneer Yangon. 14 Jul 1998. British American Tobacco (Non MSA). http:// tobacco.health.usyd.edu.au/tds/BAT_MIS 00005 [Accessed 17 May 2004].

41 Bates Advertising (Myanmar). 555 Cosmos night III: 14th August 1998 Club Pioneer Myanmar. 15 Jun 1998. British American Tobacco (Non MSA). http://tobacco.health.usyd.edu.au/tds/BAT_MIS_00006 [Accessed 17 May 2004].

42 Bates Advertising (Myanmar). 555 staying cool when its hot: August onwards 1998. 1 Aug 1998. British American Tobacco (Non MSA). http:// tobacco.health.usyd.edu.au/tds/BAT_MIS_00008 [Accessed 17 May 2004].

43 Philip Morris Asia. [Promotional campaigns and below-the-line programs] 16 Jul 1991. Philip Morris. Bates No. 2045003146/3150. http:// legacy.library.ucsf.edu/tid/wdzO3e00

44 Bates Advertising (Myanmar). Get lucky revised proposal: [proposal to BATUKE]. 12 Aug 1996. British American Tobacco (Non MSA). http:// tobacco.health.usyd.edu.au/tds/BAT_MIS_00002 [Accessed 17 May 2004].

45 Chapman S. Ad Watch: "The contemporary, irreverent brand of youth with an independent streak": BAT's youth promotions in Myanmar. Tobacco Control 2004; 13:93-4.

46 Philip Morris Asia. Marlboro Adventure Team, Asia 1994. 1 Feb 1994. Philip Morris. Bates No. 2504018491/8505. http:// legacy.library.ucsf.edu/tid/nev19e00.

47 Watson Creative Marketing. TMD for Marlboro and Chesterfield. Jan 1994. Philip Morris. Bates No. 2504015636/5736. http:// legacy.library.ucsf.edu/tid/mka42e00.

48 British American Tobacco. 555 sponsorships Asia: [note to S. Osborne forwarding draft proposal 'The way forward']. 1991. British American Tobacco. Bates No. 301633035/3038. http://www.library.ucsf.edu/ tobacco/batco/html/12800/12803 [Accessed 17 May 2004].

49 RJ Reynolds. The legend in adventure: Camel trophy Kalimantan '96. 1996. Reynolds RJ. Bates No. 522476770/6799. http://legacy.library.ucsf.edu/ $\mathrm{tid} / \mathrm{bdp} 70 \mathrm{~d} 00$.

50 Grey Direct. [Presentation on direct marketing with case studies]. 24 Nov 1993. British American Tobacco. Bates No. 301681589/1658. http:// tobaccodocuments.org/health_canada/30168155.html [Accessed 17 May 2004].

51 British American Tobacco. Kent sponsorship. Aug 1991. British American Tobacco. Bates No. 502599921/9923. hittp://tobaccodocuments.org/ guildford_misc/502599898-600019.html [Accessed 17 May 2004].

52 Philip Morris International. The activities of Philip Morris in the third world. Apr 1988. Philip Morris. Bates No. 2024261707/1719. http:// legacy.library.ucsf.edu/tid/ipx24e00.

53 Kremer B. B\&W International. Pepsi/Honda sponsorship proposal. 4 Feb 1994. British American Tobacco. Bates No. 303590489/0491. http:// tobacco.health.usyd.edu.au/tds/BAT303590489_0491 [Accessed 17 May 2004].

54 Johnstone I. TLSS briefing document: Assen, 25th June 1994. 22 Jun 1994. British American Tobacco. Bates No. 303590416/438. http:// tobacco.health.usyd.edu.au/tds/BAT303590416_0438 [Accessed 17 May 2004].

55 Ashe S. TLSS 1994 advertising campaign: status and next steps. 23 Feb 1993. British American Tobacco. Bates No. 303590478/0487. http:// tobacco.health.usyd.edu.au/tds/BAT303590478_0487 [Accessed 17 May 2004].

56 Hendricks J. Brown \& Williamson. Team Lucky Strike Suzuki support advertising, 1994/95. 1994. British American Tobacco. Bates No. 303590559/0579. http://www. library.ucsf.edu/tobacco/batco/html/ 13500/13595/ [Accessed 17 May 2004]

57 Kremer NW. Update meeting, Assen, June 25, 1994: Team Lucky Strike Suzuki world champions. 25 Jun 1994. British American Tobacco. Bates No. 303590439/0456. http://tobacco.health.usyd.edu.au/tds/ BAT303590439_0456 [Accessed 17 May 2004]

58 Hacking IG. Driving Lucky Strike: [memo to all BATCo Marketing Directors/ Managers re: New TLSS campaign]. 20 May 1994. British American Tobacco. Bates No. 303590412/0413. http:// tobacco.health.usyd.edu.au/tds/BAT303590412_0413 [Accessed 17 May 2004].

59 da Roza E. Marlboro Superbike Show 1990. 18 Sep 1990. Philip Morris. Bates No. 2504016566. http://legacy.library.ucsf.edu/tid/uga42e00.

60 British American Tobacco. Barclay Formula 1 sponsorship. 5 Jul 1989. British American Tobacco. Bates No. 301706447/6454. http:// www. library.ucsf.edu/tobacco/batco/html/17300/17392 [Accessed 13 Jul 2004].

61 Bingham P, Holroyd K. How Marlboro led the pack. Mar 1994. British American Tobacco. Bates No. 502570351/0377. http:// tobacco.health.usyd.edu.au/tds/BAT502570351_0387 [Accessed 17 May 2004].

62 Carlyle J, Collin J, Muggli M, et al. British American Tobacco and Formula One motor racing. BMJ 2004;329:104-6.

63 BBC Sport. New races added to Fl calendar. BBC. 2003. http:// news.bbc.co.uk/go/pr/fr/-/sport/formula_one/3100002.stm [Accessed $19 \mathrm{Jul} 2004]$. 
64 British American Tobacco. Lucky Strike racing exploitation. 1999. British American Tobacco. Bates No. 321350948/0954. http:// www.library.ucsf.edu/tobacco/batco/html/17400/17402 [Accessed 13 Jul 2004]

65 Dewhirst T, Hunter A. Tobacco sponsorship of Formula One and CART auto racing: tobacco brand exposure and enhanced symbolic imagery through co-sponsors' third pary advertising. Tobacco Control 2002;11:146-50.

66 Blum A. The Marlboro Grand Prix: circumvention of the television ban on tobacco advertising. N Engl J Med 1991;324:913-17.

67 Parke R. Masterminding a special gamble. South China Morning Post 18 Nov 1984.

68 British American Tobacco. 555 State Express 1993 brand plans. 1993. British American Tobacco. Bates No. 500259510/9533. http:// tobaccodocuments.org/psc_who/PSC183.html [Accessed 17 May 2004].

69 Assunta M. BAT flouts tobacco-free World Cup policy. Tobacco Control 2002;11:277-8.

70 Pro Tennis Management. Salem Open: Japan management agreement. 9 Nov 1992. R.J. Reynolds. Bates No. $516411280 / 1295$. http:// legacy.library.ucsf.edu/tid/iij82d00.

71 Philip Morris USA. [Letter to Billie Jean King]. 19 Jan 1989. Philip Morris. Bates No. 2043659666/9668. http://legacy.library.ucsf.edu/tid/ Iwv06e00.

72 Philip Morris Asia. [Draft letter to Michael Chang]. 1992. Philip Morris Bates No. 2504004008/4010. http://legacy.library.ucsf.edu/tid/ evd71f00.

73 Ernster VL, Kaufman N, Nichter M, et al. Women and tobacco: moving from policy to action. Bull World Health Organ 2000;78:891-901.

74 British American Tobacco. Benson \& Hedges - guidelines for photography. 14 Mar 1994. British American Tobacco. Bates No. 500245491. http:// tobacco.health.usyd.edu.au/tds/BAT500245491 [Accessed 17 May 2004]

75 Leiber C. [Memo to David Dangoor]. 25 Oct 1989. Philip Morris. Bates No. 2504034812/4813. http://legacy.library.ucsf.edu/tid/eug19e00.

76 Carter S. Going below the line: creating transportable brands for Australia's dark market. Tobacco Control 2003;12(suppl III):iii87-94.

77 Philip Morris Asia. Virginia Slims below-the-line programs: Guam, Hong Kong, Japan, Korea, Taiwan. July 1991. Philip Morris. Bates No. 2500136416/6462. http://legacy.library.ucsf.edu/tid/isk19e00

78 Philip Morris. Allegations and responses. Apr 1998. Philip Morris. Bates No. 2072520796/0823. http://legacy.library.ucsf.edu/tid/iib06c00.

79 Philip Morris International. Philip Morris Asia region overview. Mar 1990 Philip Morris. Bates No. 2501081755/1849. http:// legacy.library.ucsf.edu/tid/zac29e00

80 O'Keefe A, Pollay RW. Deadly targeting of women in promoting cigarettes. J Am Med Womens Assoc 1996;51:67-9.

81 Boyd TC, Boyd CJ, Greenlee TB. A means to an end: slim hopes and cigarette advertising. Health Promot Pract 2003;4:266-77.

82 Ernster VL. Women, smoking, cigarette advertising and cancer. Women's Health 1986;11:217-35.

83 Amos A, Haglund M. From social tobacco to "torch of freedom": the marketing of cigarettes to women. Tobacco Control 2000;9:3-8.

84 Philip Morris International. Virginia Slims. 1986. Philip Morris. Bates No. 2500156671/6681. http://legacy.library.ucsf.edu/tid/uwb42e00.

85 Michael Normile Marketing. Young, light and menthol oriented smokers: Hong Kong market opportunity study. Feb 1989. Philip Morris. Bates No. 2500132081/2158. http://legacy.library.ucsf.edu/tid/psd42e00.

86 Philip Morris Asia. Hong Kong YAMS study 1993: a study of values, lifestyles, and brand images among Hong Kong young adult male smokers. Jan 1994. Philip Morris. Bates No. 2504053220/3298. http:// legacy.library.ucsf.edu/tid/ezw32e00.

87 Hill and Knowlton Asia. Philip Morris Asia research discussion paper: Marlboro smokers research. 1993. Philip Morris. Bates No. 2504029339/ 9347. http://legacy.library.ucsf.edu/tid/rcul9e00.

88 Research International Asia. A study of values, lifestyles, and brand images among Taiwanese young adult male smokers. 27 Jul 1994. Philip Morris.
Bates No. 2504053019/3024. http://legacy.library.ucsf.edu/tid/ sex32e00.

89 Philip Morris Asia. Research overview of Singapore, Malaysia, Thailand. Jan 1991. Philip Morris. Bates No. 2504028621A/8726. http:// legacy.library.ucsf.edu/tid/idu19e00.

90 Philip Morris. Malaysia Marlboro image study. 1992. Philip Morris. Bates No. 2504019106/91 18. http://legacy.library.ucsf.edu/tid/mpa42e00.

91 Framework Convention Alliance. Declaration by ASEAN countries on the Framework Convention on Tobacco Control. 2002. http://fctc.org/ archives/Declaration_Bangkok.shtml [Accessed 20 Jul 2004].

92 International Olympic Committee. Calgary 1988 - did you know? http:// www.olympic.org/uk/games/past/innovations_uk.asp?OLGT = 2\&OLGY = 1988 [Accessed 17 May 2004].

93 Cooper K. Tobacco sponsorship in football: the position of FIFA, 2000. http://www.wpro.who.int/tfi/docs/wntd02/Federation Internationale de Football Association.doc [Accessed 19 July 2004].

94 Rivera B. RP to hold tobacco-free SEA Games next year. Inquirer News Service (Manila). 2004. http://www.inq7.net.spo/2004/jun/02/text/ spo_5-1-p.htm [Accessed 20 Jul 2004].

95 Federation International de 'IAutomobile. Tobacco sponsorship of motor sport achieving an effective ban by world-wide agreement in 2006. Paris: FIA, 2002. http://www. fia.com [Accessed 6 Jan 2004].

96 BBC Sport. Europe's Fl future on the brink. BBCi. 2002. http:// news.bbc.co.uk/sportl/hi/motorsport/formula_one/2570521.stm [Accessed 19 Jul 2004].

97 BBC Sport. Fl makes tobacco U-turn. BBC. 2003. http://news.bbc.co.uk/ $\mathrm{go} / \mathrm{pr} / \mathrm{fr} /-$ /sportl/hi/motorsport/formula_one/3020348.stm [Accessed 19 July 2004]

98 British American Tobacco, Compania Industrial de Tabacos SA, Grupo Iberoamericano de Fomento SA, et al. International Tobacco Products Marketing Standards. 2001. http://www.batmalaysia.com/subnav/ marketingstandard/InternationalMarketingStandards.pdf [Accessed 17 May 2004].

99 Hagmann M. WHO attacks tobacco sponsorship of sports. Bull World Health Organ 2002;80:80-1.

100 Chitanondh H. BAT sponsorship of World Soccer telecast in Malaysia: [email to the President of the Football Association of Malaysia on 27 May 2002]. 2002. http://lists.essential.org/pipermail/intl-tobacco/2002q2/ 000740.html [Accessed 17 May 2004].

101 The Nation. FIFA in tobacco advertising furore. The Nation (Thailand) 31 May 2002. http://tobaccodocuments.org/enews/94928.html [Accessed 17 May 2004].

102 Lawton C. Cigarette ads butt in at World Cup, despite a tobacco ban. The Wall Street Journal (New York) 18 Jun 2002:B1.

103 DeLand K, Lewis K, Taylor A. Developing a public policy response to the toabcco industry's targeting of women and girls: the role of the WHO Framework Convention on Tobacco Control. J Am Med Womens Assoc 2000;55:316-20.

104 World Health Organization. "Young women's smoking crisis" set to hit Asia. $15 \mathrm{Nov}$ 1999. (Press release; WHO/69). http://www.who.int/inf-pr1999/en/pr99-69.html [Accessed 17 May 2004].

105 US Department of Health and Human Services. Women and smoking: a report of the Surgeon General. Rockville, Maryland: US Department of Health and Human Services, Public Health Service, Office of Smoking and Health, 2001.

106 US Department of Health and Human Services. The health consequences of smoking for women. A report of the Surgeon General, 1980. Rockville, Maryland: Office of the Assistant Secretary for Health, Office on Smoking and Health, 1980 (DHHS Publication No (CDC) 90-8416)

107 Bianco M, Haglund M, Matsui $Y$, et al. The international women's movement and anti-tobacco campaigns. In: Samet J, Yoon S-Y, eds. Women and the tobacco epidemic: challenges for the 21 st century. Geneva: World Health Organization in collaboration with the Institute for Global Tobacco Control, Johns Hopkins School of Public Health, 2001:209-15. 